\title{
A FUNCTIONAL ELECTRIC ORTHESIS ON THE PARETIC LEG IMPROVES QUALITY OF LIFE OF STROKE PATIENTS
}

\author{
Mara Renata Fernandes', Luciane B.C. Carvalho², Gilmar F. Prado ${ }^{3}$
}

\begin{abstract}
Context: Hemipa resia changes quality of life of patients with stroke making difficult a normal life. Objective: To evaluate the effect of Functional Eletric Orthesis (FEO) applied over the paretic leg in the quality of life of stroke patients. Method: The quality of life of 50 stroke patients of Associacao de Assistencia a Crianca Deficiente (AACD) was evaluated with SF-36 questionnaire before and after the tre atment with a FEO for rehabilitation of walking. We analyzed data according to gender and affected hemisphere. Results: The average values from all domains of SF-36 improved significantly $(p<0.001)$. Female patients improved more than male in Emotional Domain $(p=0.04)$ and presented a trend to be better regarding Bodily Pain and Social Functioning. Patients with right hemiparesia improved more than those with left hemiparesia $(p=0.02)$. Conclusion: FEO over a paretic leg is efficient to improve quality of life of stroke patients, mainly Physical Functioning.
\end{abstract}

KEY WORDS: stroke, quality of life, functional eletric orthesis, SF-36.

\section{Órtese elétrica funcional usada no membro inferior parético melhora a qualidade de vida em pacientes com acidente vascular encefálico}

\begin{abstract}
RESUMO - Contexto: A hemiparesia altera a qualidade de vida de pacientes com acidente vascular encefálico (AVE) dificultando uma vida normal. Objetivo: Avaliar o efeito da Órtese Elétrica Funcional (OEF) colocada na perna parética, sobre a qualidade de vida de pacientes com AVE. Método: A qualidade de vida de 50 pacientes da AACD foi avaliada pelo questionário SF-36 antes e após o tratamento com OEF. Os dados foram analisados segundo sexo e lado do corpo acometido pelo AVE. Resultados: As médias em todas as categorias do SF-36 foram significantemente maiores após tratamento com OEF $(p<0,001)$. Pacientes do sexo feminino apresentaram resultados superiores aos do sexo masculino nos Aspectos Emocionais $(p=0,04)$ e apresentaram tendência a melhora em Dor e Aspectos Sociais. Pacientes com hemiparesia dire ita obtiveram resultados superiores aos com hemiparesia esquerda nos Aspectos Emocionais $(p=0,02)$. Conclusão: A utilização da OEF na perna parética por AVE é eficaz em melhorar a qualidade de vida dos pacientes.
\end{abstract}

PALAVRAS-CHAVE: acidente vascular encefálico, qualidade de vida, órtese elétrica funcional, SF-36.

Stroke is a highly prevalent disease and is the leading cause of death in Brazil ${ }^{1-3}$. In the United States occur 165,000 deaths in 700,000 strokes, each year ${ }^{4}$. Approximately $70 \%$ recover their normal gait within one year, 45 to $60 \%$ are able to handle their personal care without assistance, and 5 to $9 \%$ become fully independent. Professionally, $9 \%$ re tu rn to their original jobs, $1 \%$ changes their occupation, $33 \%$ never return to the working world, and $57 \%$ remain unemployed ${ }^{5}$. Hemiparesia associated to stroke not only causes serious motor limitations but also interferes in patients' social activities, relationships, and emotional life, directly reducing the quality of their lives. The quality of life of stroke patients can be seriously reduced, and for this reason, there has been a g rowing interest among doctors and researchers in assessing stroke patients' quality of life and in proposing therapies for rehabilitation. Physicians and physiotherapists play a fundamental role in recovering patients' quality of life by providing the support required to stabilize the patient's medical condition (vital and motor functions), offering the patient and family members guidance and developing an individual treatment to recover functions, comprising relaxation exercises and stretching, moving of joints, global muscular strengthening and body awareness.

Departments of Neurology and Internal Medicine, Federal University of Sao Paulo (UNIFESP), Sao Paulo, SP, Brazil: ${ }^{1}$ Physiotherapist; ${ }^{2} \mathrm{PhD} ;{ }^{3} \mathrm{MD}, \mathrm{PhD}$.

Received 13 April 2005, received in final form 8 August 2005. Accepted 1 October 2005. 
Foot dorsal flexion is an important function that is lost in stroke patients, resulting in a dropped foot, causing an abnormal gait which leads to sprains and falls, and affects the patient's independence ${ }^{6}$. Tre atment with a Functional Electric Orthesis (FEO) over the anterior tibialis and fibular muscles of the affected leg may help patient to recover. The FEO has shown to be more advantageous than the conventional orthesis (ankle foot orthesis-AFO) as it is light $(35 \mathrm{~g})$ and the patient can use the same shoe size and also can keep a free ankle joint movement. The FEO also permits foot dorsal flexion resulting in a more functional gait, avoiding sprains and falls and, as the ankle is kept stable, the patient's walking speed increases and the Physiological Cost Index - PCl is reduced $^{7}$. All of these factors seem to exert a positive influence on the lives of these patients.

Accordingly, this study seeks to assess changes in the quality of life of hemiparetic patients submitted to treatment with a FEO with the SF-36 questionnaire.

\section{METHOD}

The study was carried out at the Associacao de Assistencia a Crianca Deficiente (AACD - Association to Assist Deficient (Children). The participants were 50 hemiparetic patients recruited from the Acquired Encephalic Lesions Outpatient clinic - AEL, who accepted participating in the study by signing the informed consent form (Process \# 0280/02).

Participants - This comparative trial was carried out among individuals of the same group and aimed to assess and analyze patients' quality of life at the beginning and at the end of the training period. Study participants were hemiparetic male and female walking patients above 18 years of age, cooperative, having at least degree 1 of muscular strength in tibialis anterior and fibular muscles with no structu red deformities. The trial participants did not include patients with cardiac pacemakers, local vascular alterations or sensibility problems in the hemiparetic lower limb, or those with severe spasticity, structural deformities, limited ankle and foot joint movement, or significant obesity (BMI > 30) as well as pregnant women and patients with cognitive deficiencies.

FEO - Patients were treated with an electric orthesis that permits foot dorsal flexion control when walking, primarily in the balance phase giving a correct hell strike. Stimulation is applied through skin-surface electrodes placed on the motor points of the patient's tibialis anterior and fibular muscle, and a compact functional electrical stimulation device (microfes) is connected to the patient's leg with a Ve I crostrip to stimulate contraction of muscles no longer controlled by the nervous system. An inner sole is placed under the heel of the shoe and connected to the $\mathrm{microfes}$. The stimulator's output is triggered by heel rise resulting in dorsal flexion; the stimulation is interrupted upon heel strike.

Intenention - The treatment was applied in 20 sessions divided into two phases. The first phase of the trial involved muscle training whereby the patient's tibialis anterior and fibular muscles were trained by using a conventional functional electrical stimulator while the patient was sitting. Contractions were stimulated for 5 seconds within 10-second intervals. This training continued until the patient en$\mathrm{d}$ u red 30 minutes of dorsal flexion without fatigue, that is, without decrease in the movement. This phase comprised 10 sessions with two-day intervals between each session. The patient then initiated the second phase of treatment in which a FEO was used. Intensity of the stimulus was adjus-

Table. Mean values and the Standard Deviation of differences in score of the SF-36 domains before and after treatment with a Functional Electric Orthesis (FEO).

\begin{tabular}{ccccc}
\hline Domains & \multicolumn{2}{c}{ Mean } & Before \\
$\mathrm{m} \pm \mathrm{sd}$ & $\begin{array}{c}\text { After } \\
\mathrm{m} \pm \mathrm{sd}\end{array}$ & $\begin{array}{c}\Delta \mathrm{m} \\
\mathrm{m} \pm \mathrm{sd}\end{array}$ & $\mathrm{P}$ \\
\hline $\mathrm{PF}$ & $44.50 \pm 21.46$ & $65.90 \pm 18.03$ & $21.40 \pm 16.38$ & 0.0001 \\
$\mathrm{MH}$ & $65.20 \pm 24.00$ & $79.52 \pm 14.87$ & $14.32 \pm 13.79$ & 0.0001 \\
VIT & $58.20 \pm 21.85$ & $72.40 \pm 16.36$ & $14.20 \pm 15.06$ & 0.0001 \\
SF & $63.50 \pm 29.00$ & $82.500 \pm 17.13$ & $19.000 \pm 24.12$ & 0.0001 \\
RE & $55.99 \pm 45.40$ & $87.99 \pm 26.75$ & $32.00 \pm 40.39$ & 0.0001 \\
RP & $32.50 \pm 44.39$ & $51.50 \pm 46.95$ & $19.00 \pm 38.32$ & 0.001 \\
GH & $69.28 \pm 22.75$ & $75,22 \pm 22.44$ & $5.94 \pm 9.82$ & 0.0001 \\
BP & $75.96 \pm 24.44$ & $83.62 \pm 21.70$ & $7.66 \pm 16.41$ & 0.002 \\
\hline
\end{tabular}

PF, physical functioning; $\mathrm{MH}$, mental health; VIT, vitality; SF, social functioning; RE, role emotional; RP, role physical; $\mathrm{GH}$, general health; $\mathrm{BP}$, bodily pain; $\Delta \mathrm{m}$, difference in the means of SF36; $\mathrm{m}$, mean; sd, standard deviation. 
ted to allow foot rise without any discomfort. Gait training was carried out according to a course established for all patients at the beginning of the trial and included level and uneven ground, going up and down slopes, ramps and stairs. This phase continued until patients were able to walk for 30 minutes without fatigue and included 10 sessions with two-days intervals between each session. Patients were submitted to a quality of life assessment beforeand after treatment measured by SF-36 (Measuring Outcomes Study Short-Form-36) ${ }^{8}$ translated and validated for Brazilian Portuguese Language and Culture ${ }^{9}$. Each patient was evaluated in relation to: Physical Functioning (PF), the patient's difficulties in carrying out daily activities such as walking, lifting objects, dressing, going up and down stairs, and taking a bath; Mental Health $(\mathrm{MH})$, feelings of $n$ e rvousness and depression vs. feelings of happiness and well-being; Role Emotional (RE), to what degree the patient's emotional problems interfere in work and daily activities; Vitality (VIT), to what extent the patient has felt energetic or tired; Social Functioning (SF), how physical health or emotional problems interf e re in social activities such as visiting friends, going to movies; Role Physical (RP), to what d e g ree the patient's disability interf e res in work or daily activities; General Health (GH), an evaluation by which the patient classifies his/her own health and feelings in relation to other persons; and Bodily Pain (BP), pain intensity and how much it interferes in the patient's life inside and outside the home.

Statistical analysis - For each SF-36 domain the difference between the scores before and after treatment was calculated for mean, median, standard deviation and minimum and maximum ratings (Table). Data that were normally distributed are shown as mean \pm standard deviation. The Student T Test was used to detect possible mean score differences before and after treatment in each domain. Gender and body side affected by the lesion were also analyzed in all SF-36 domains. We adopted $p<0.05$ in order to determine any association among the variables.

\section{RESULTS}

The trial results showed a significant difference between the SF-36 domains at the beginning and the end of treatment $(p<0.001)$. The 50 patients submitted to this study showed improvement in all SF-36 categories: PF, MH, VIT, SF, RE, RP, GH and BP. Among the categories evaluated in the questionnaire, PF was the variable in which the patients recorded the most outstanding improvement. In other words, the final PF score was by far higher than that re corded at the beginning of treatment.

After treatment with FEO, 45 patients (90\%) imp roved their PF $(p<0.001)$ and only 5 patients $(5 \%)$ did not improve significantly. $\mathrm{MH}$ was the second domain in which patients showed significant impro v ement ( $p<0.001), 39$ patients $(78 \%)$ showed improvement after treatment and 11 patients (22\%) main- tained their initial score. Positive results were also recorded for VIT $(p<0.001)$ for 33 patients $(66 \%)$ who showed improvement while 17 patients (34\%) maintained their initial score. The outcome for SF was also positive $(p<0.001), 30$ patients $(60 \%)$ recorded improvement after treatment and 20 patients (40\%) maintained their initial score. The results of the RE showed that 23 patients $(46 \%)$ presented improvement and 27 patients $(54 \%)$ maintained their initial score $(\mathrm{p}<$ $0.001)$. For RP, 17 patients (34\%) showed improve ment while 32 patients (64\%) maintained the same score $(p<0.001)$. In this domain just 1 patient $(2 \%)$ worsened. For $\mathrm{GH}, 22$ patients (44\%) improved and 27 patients $(54 \%)$ maintained their initial score $(\mathrm{p}<$ $0.001)$. In this domain, 1 patient $(2 \%)$ showed a change for worse in general health after treatment. For BP, $15(30 \%)$ improved, 33 patients $(66 \%)$ maintained their initial score $(p<0.001)$, and $2(4 \%)$ reported more pain after treatment. Female (mean $=39.51 \pm 43.40)$ i $m$ p roved more than male (mean $=23.19 \pm 35.44$ ) for $\operatorname{RE}(p=0.04)$ and also showed a trend to be better rega rding $B P(p=0.06)$ and $S F(p=0.07)$. For $R E$, patients with right hemiparesia improved more than those with left hemiparesia $(50.0 \pm 48.2 ; 26.3 \pm 36.5$; respectively, $p=0.02$ ).

\section{DISCUSSION}

Stroke rehabilitation is a slow learning process aimed at maximizing patients' potentials and reintegrating them into the community, considering their quality of life. Physical functioning (PF) is an extremely important information for physiotherapy, as it shows how the motor disability and sensitiveness caused by the lesion interfere in daily activities. It also provides important data when preparing a rehabilitation program and evaluating the intervention results.

In this trial, PF was the domain in which patients showed the best improvement with use of a FEO. FEO is becoming a valuable substitute for the conventional orthesis. FEO improves gait kinematics in adults with motor disorders by restoring the electromiographic registers of the cyclic muscle activity while walking $^{10}$.

Several studies in literature have also mentioned improvement of up to two degrees in muscular $s$ t rength, which is directly related with PF; an accentuated and permanent improvement in spasticity; accentuated and stable improvement in gait, increased walking speed, reduction of the $\mathrm{PCl}$, carry-over effect, motor relearning, and biomechanical changes with use of the FEO ${ }^{11-12}$. All of these factors are pos- 
itive for patients allowing an improvement on quality of life.

A positive result for $\mathrm{MH}$ can be related in some degree to a reduction in depression, and to an increased sense of well being.

By improving patients' gait, FEO allows patients to carry out daily activities independently with less effort and in less time. This directly affects the VIT domain, which also showed a positive outcome with treatment. The same results were recorded for the SF domain as an improved gait increases security to face the challenges to be met outside the home.

Assessment of the RE, RP, GH, and BP showed significant improvement with a FEO; however variations in SF measurements before and after treatment were not as numerically expressive as those re co rded for $\mathrm{PF}, \mathrm{MH}, \mathrm{VIT}$, and SF. Several patients mentioned that their $\mathrm{GH}$ and $\mathrm{BP}$ condition had worsened by using the FEO. The BP domain within the SF-36 takes into consideration what the patient is feeling or experiencing as a whole. Some patients reported pain in the shoulder affected, and some complained of lower back pain. No patient recorded or began to note any pain where the FEO was placed. Shoulder pain is due to absence of movement and improper handling of the patient while lower back pain is often the result of gait compensation associated with muscular imbalance in the trunk after the lesion. The high percentage of patients that did not show improvement in pain is justified by the fact that a FEO aids in recovering a function that has been lost, but its purpose is not to alleviate the condition of pain in distant segments of the leg. The regions affected by pain should be treated separately with specific resources intended for this purpose.

In our practice we have noticed that women had a better prognosis in recovery after stroke, and also those patients with right side of affected body. Interestingly our data have shown that female patients finished the study with a better quality of life in the $\mathrm{RE}$ and possibly in BP and SF. Functional differences between male and female brains ${ }^{13}$ may be attempted to explain that finding. Well known differences between cerebral hemisphere ${ }^{14}$ can also be enrolled to justify a better improvement detected on those patients with right hemiparesia.

It is interesting to note that although the functional improvement in gait was quite evident, as recorded for $90 \%$ of the study participants, the patients' perception of this in relation to their overall quality of life was not expressive, and for this reason several patients evaluated their condition in the $\mathrm{GH}$ domain as being worse. One explanation for this may be the overall repercussions produced by the stroke in patients, including in their psychological condition. Although the study patients were relatively rehabilitated physically, they did not adapt to their new condition, which created an inner scenario that impaired their "full recovery". In view of this, we recommend a multidisciplinary approach to rehabilitation within which psychological assistance would be fundamental in helping patients and their families handle the limitations and perspectives to be considered after a stroke ${ }^{15-20}$.

Acknowledgments - To Marcia Maiumi Fukujima.

\section{REFERENCES}

1. Lotufo PA. Mortalidade pela doença cerebrovascular no Brasil. Rev Bras Hipertens 2000;7:387-391.

2. Saposnik G, Del Brutto OH. Stroke in South America: a systematic review of incidence, prevalence, and stroke subtypes. Stroke 2003; 34:2103-2108.

3. Lotufo PA, Bensenor IM. Stroke mortality in São Paulo (1997-2003): a description using the Tenth Revision of the International Classification of Diseases. Arq Neuropsiquiatr 2004;62:1008-1011.

4. Ingall T. Stroke: incidence, mortality, morbidity and risk. J Insur Med 2004;36:143-152.

5. Otaola P, DelaViela FM. Valor de la classification in el pacient hemiplijico tras un ictus. Rev Neurol 2000;31:1151-1154.

6. Granat MH, Maxwell DJ, Ferguson ACB, Lees KR, Barbenel JC. Peroneal stimulator: evaluation for the correction of spastic drop foot in hemiplegia. Arch Phys Med Rehabil 1996;77:19-24.

7. Burridge J, Taylor P, Hagan S, Swain I. Experience of clinical use of the Odstock Dropped Foot Stimulator. Artificial Organs 1997;21:254-260.

8. Ware JE, Sherbourne, CD. The MOS 36-Item Short-Form Health Survey (SF-36): conceptual framework and item selection. Med Care 1992;30: 473-483.

9. Ciconelli RM. Tradução para o português e validação do questionário genérico de avaliação de qualidade de vida "Medical Outcomes Study 36-Item Short-Form Health Survey (SF-36). Dissertação de Mestrado, Universidade Federal de São Paulo 1997.

10. Gracinin F. Functional electrical stimulation in control of motor output and movements. Contemp Clin Neurophysiol 1978;34:355-368.

11. Merletti R. Clinical Experience of eletronic peroneal stimulators in 50 hemiparetic patients. Scand J Rehab Med 1979;11:11-121.

12. Fonseca APC, Fonseca GA, Araujo DP. Utilização da OEF KM 25 em pacientes hemiparéticos. Med Reab 1996;43:5-11.

13. Geschwind N. Specialization of the human brain. Sci Am 1979;241: 180-199.

14. Gazzaniga M. The social brain: discovering the networks of the mind. New York: Basic Books, 1985.

15. Cavalcanti JLS. O que fazer diante do doente com depressão após AVE. Associação Brasileira de Neuropsiquiatria Geriátrica - Boletim Científico 2003. Ano I - (1):1-3.

16. Bottino CMC. A visão psiquiátrica do doente pós AVE. Associação Brasileira de Neuropsiquiatria Geriátrica - Boletim Científico 2003; (1): 4-5.

17. Pereira AP, Pimenta CR, Nogueira D, Silva ML, Tomás MT. Intervenção da família na reabilitação do doente com AVE. Jornal Hospital Curry Cabral 1998;1-11.

18. Evans RL, Bishop DS, Matlock AL. Family interaction and treatment adherence after stroke. Arch Phys Med Rehabil 1987;68:513-517.

19. Landau P. Rehabilitation: does it make a difference? Aust Fam Physycian 1997;26:1157-1161.

20. Reddy MP, Reddy V. After a stroke: strategies to res to refunction and prevent complications. Geriatrics 1997;52:59-75. 